Supporting Information for

\title{
Assessing Contamination of Stream Networks Near Shale Gas Development Using a New Geospatial Tool
}

Amal Agarwal ${ }^{\ddagger}$, a, Tao Wen ${ }^{*}, \mathrm{~b}$, Alex Chen ${ }^{\mathrm{a}}$, Anna Yinqi Zhang ${ }^{\mathrm{a}}$, Xianzeng Niu ${ }^{\mathrm{b}}, \mathrm{Xiang}_{\text {Zhan }}^{\mathrm{c}}$, Lingzhou Xue ,a, Susan L. Brantley ${ }^{\mathrm{b}, \mathrm{d}}$

aDepartment of Statistics, Pennsylvania State University, University Park, PA 16802, United States

${ }^{b}$ Earth and Environmental Systems Institute, Pennsylvania State University, University Park, PA 16802, United States

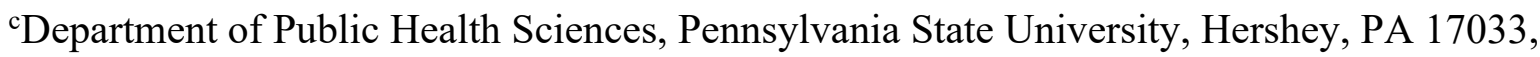
United States

dDepartment of Geosciences, Pennsylvania State University, University Park, PA 16802, United States

$\$$ These authors contributed equally to this work.

${ }^{*}$ Corresponding author: Lingzhou Xue (1zxue@psu.edu), Tao Wen (wwen08@syr.edu)

SI file includes four SI Text, eight SI Figures, and eleven SI Tables 


\section{Text S1 Additional Notes for GeoNet Framework}

\section{Preprocessing Data of Stream Network, Stream Chemistry, and Testing Event}

Stream Data. The shapefile of stream flowlines is transformed to a directed network that is represented by a two-column edge list of the intersections. River flowlines connect all the intersections in the edge list and form nodes in the river network. We remove all isolated nodes that do not correspond a real stream flowline. The specification of the corresponding intersections indicates the direction of stream water flow from the start node ID to the end node ID. The stream order depends on the hierarchical tree structure of sub-tributaries joining the main tributary. Figure S1 gives an illustration of this directed streamflow network over eight intersections (or nodes). The stream order is represented over the arrows by a circled numeric value. Table S1 shows the corresponding edge list after preprocessing. Furthermore, all nodes are uniquely identified by their spatial coordinates, i.e. latitude and longitude. In the second step of preprocessing, we extract a sequence of spatial coordinates describing the actual curved path of the stream water flow. This sequence is a sub edge list with finer resolution and is expected to be of size 15-20 on average per edge for all streams (edges) in PA dataset. We refer to all points in this sub edge list as sub-nodes and the directed connections as sub edges. We store all of these sequences in a list with elements uniquely identified by the pairs of nodes forming the edges. This list has been referred to as the Stream Path List (SPL) in the main text.
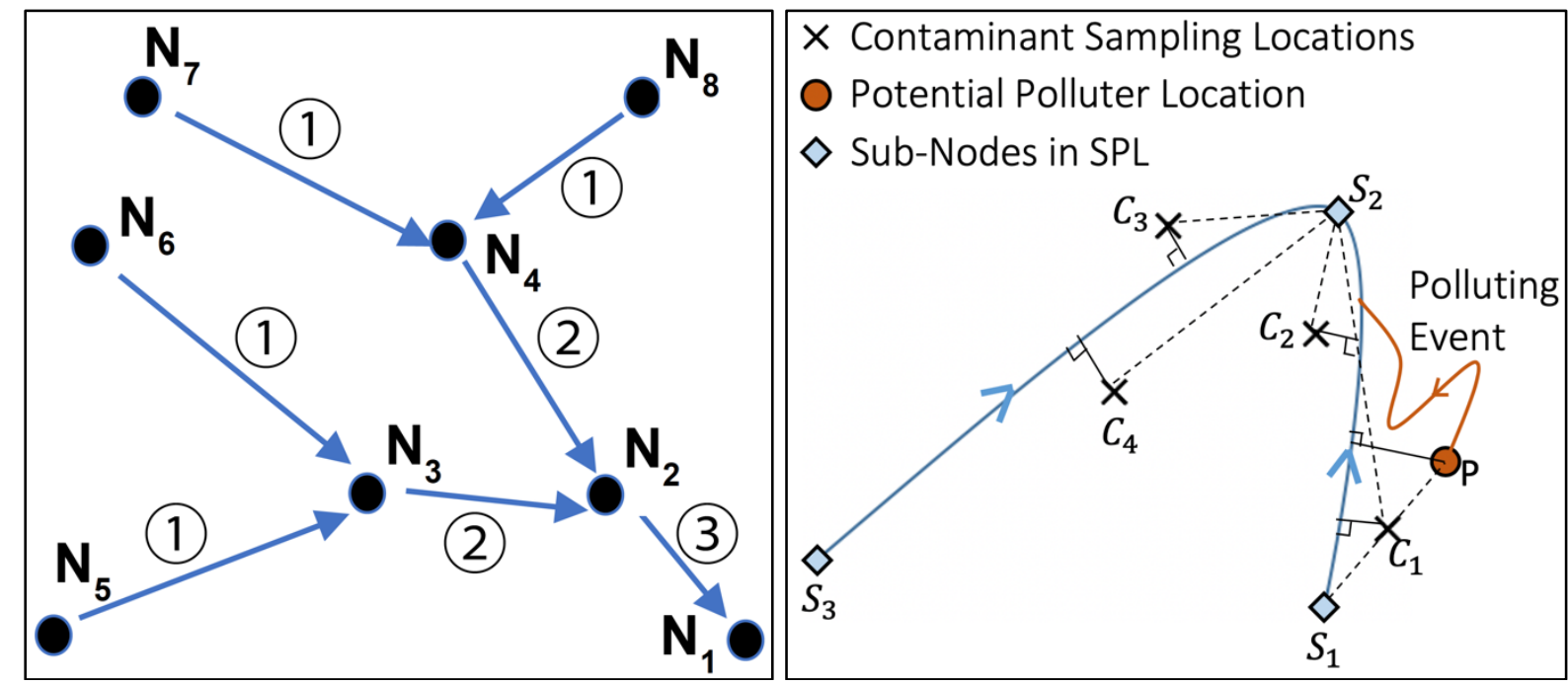

Figure S1. Illustration of (left) a subset of directed river network with 8 intersections and (right) mapping errors in the three-step hierarchical mapping procedure. $\mathrm{N}_{1}-\mathrm{N}_{8}$ represent the intersection node of two stream edges. $\mathrm{S}_{1}-\mathrm{S}_{3}$ represent sub-nodes in SPL (see text for details). $\mathrm{C}_{1}$ - $\mathrm{C}_{4}$ (i.e., contaminant sampling locations) are the locations of collecting stream chemistry samples. These 
sampling sites might sometimes be mapped not exactly on flowlines due to the uncertainty in location coordinates.

Table S1. Edge list for directed sub river network depicted in Figure S1.

\begin{tabular}{cc}
\hline Start Intersection (Node) ID & End Intersection (Node) ID \\
\hline$N_{2}$ & $\mathrm{~N}_{1}$ \\
$\mathrm{~N}_{3}$ & $\mathrm{~N}_{2}$ \\
$\mathrm{~N}_{4}$ & $\mathrm{~N}_{2}$ \\
$\mathrm{~N}_{5}$ & $\mathrm{~N}_{3}$ \\
$\mathrm{~N}_{6}$ & $\mathrm{~N}_{3}$ \\
$\mathrm{~N}_{7}$ & $\mathrm{~N}_{4}$ \\
$\mathrm{~N}_{8}$ & $\mathrm{~N}_{4}$ \\
\hline
\end{tabular}

Stream Chemistry. The preprocessing step is targeted towards removing missing values, checking for measurement errors and verifying whether all concentrations are recorded in same units. We structure unique coordinates in a single data frame in which each element points to a temporal sequence of samples (stored in a separate list) at that coordinate.

Testing Event. The data for each event that is to be tested includes location and date/time information. These events are aggregated by day. In the case study presented in this paper, the event data refer to spill incidents.

\section{Implications of the Magnitude of the River Network}

The size of the Stream Path List (SPL) could be huge. For example, for PA datasets, BRN consists of $\sim 124 \mathrm{~K}$ unique streams, and SPL contains around $\sim 1.5 \mathrm{M}$ separate coordinates. A naïve approach could proceed with mapping each contaminant sampling and potential polluter location (henceforth called C-P locations) onto streams by calculating geodesics with each coordinate in the SPL. In the stream chemistry data discussed in this work, we have $\sim 5 \mathrm{~K}$ unique sampling locations for chloride. This would require calculation of $\sim 7.5 \mathrm{~B}$ geodesics which could take a huge amount of computational time, possibly even several days without parallelization. In general, the time complexity will quickly become infeasible for even larger BRNs or with larger datasets of stream chemistry. To resolve the computational time limitations arising from processing these big datasets, we proposed a three-step hierarchical mapping procedure. Our algorithm is optimized to deal with larger datasets than that discussed in this work. 

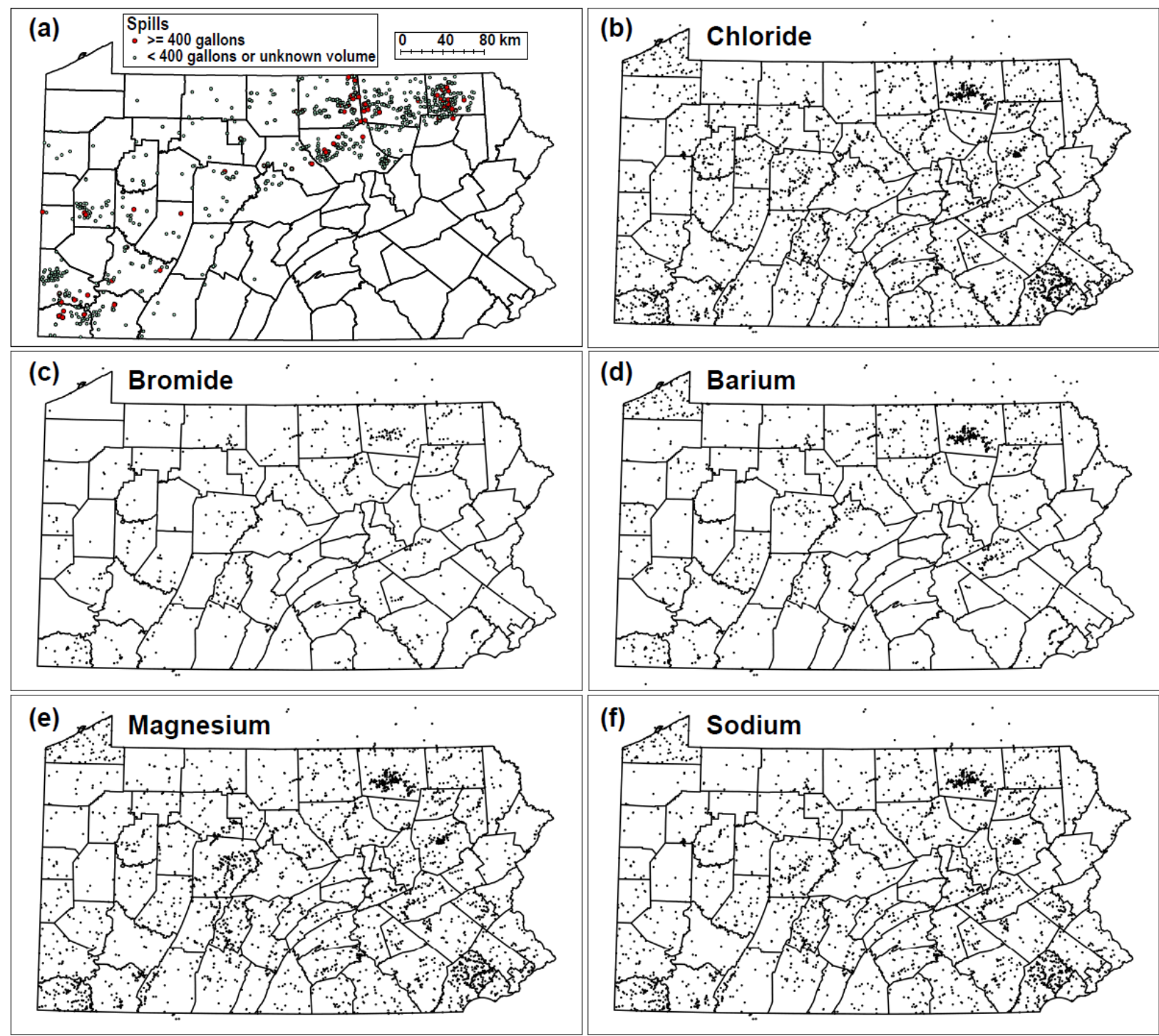

Figure S2. (a) Location of spills tested in this study. These spills were summarized and reported in the literature ${ }^{1,2}$. (b-f) Location of water quality measurements of each analyte accessible through the Water Quality Portal (https://www.waterqualitydata.us/).

\section{Discretization Errors in the Mapping Procedure and their Solutions}

Typically, a stream reach is at least a few hundred meters in length. Although we considerably reduce mapping errors in the second step, we could still lose a lot of power in our two sample tests conducted later, due to discretization errors of stream paths. This approximation is a limitation of discrete coordinates in SPL. For example, in Figure S1, the testing event (noted as "potential polluter location" in the figure) $\mathrm{P}$ must be mapped on the point where the perpendicular from $\mathrm{P}$ intersects the sub-streamline S1-S2. Similarly, the contaminant (or stream chemistry) sampling locations $\left\{C_{i}\right\}_{i=1}^{4}$ must be mapped at the intersections of their respective perpendiculars on the 
nearest sub-streams. However if we assume that sub-stream reach S1-S2 is resolved at the finest granularity in SPL i.e. there is no coordinate measured between sub-nodes S1 and S2, then at the end of the two steps we map P on S1 and $\left\{C_{i}\right\}_{i=1}^{4}$ on S2. Hence $\left\{C_{i}\right\}_{i=2}^{4}$ sites are all treated as downstream locations. This would induce an error in testing procedure because $\left\{C_{i}\right\}_{i=3}^{4}$ should not be considered as downstream sites for $\mathrm{P}$ although $C_{2}$ is a downstream sampling site for $\mathrm{P}$.

In particular, the mapping could be influenced by two possible geometrical configurations of a C-P location relative to the nearest stream with intersection nodes as $N_{1}$ and $N_{2}$ and sub-nodes as $\left\{S_{i}\right\}_{i=1}^{3}$ (Figure S3). Note that, $\angle P N_{1} S_{1}$ could be acute (a) or obtuse (b) depending on whether the C-P location lies within the span of the stream or beyond the end node $N_{1}$ of the stream. We use the law of cosines to determine this angle from the distance $N_{1} S_{1}$ extracted from SPL and the calculated geodesics $P N_{1}$ and $P S_{1}$ :

$\angle P N_{1} S_{1}=\cos ^{-1}\left(\left(P N_{1}{ }^{2}+N_{1} S_{1}^{2}-P S_{1}^{2}\right) /\left(2 \times P N_{1} \times N_{1} S_{1}\right)\right)$

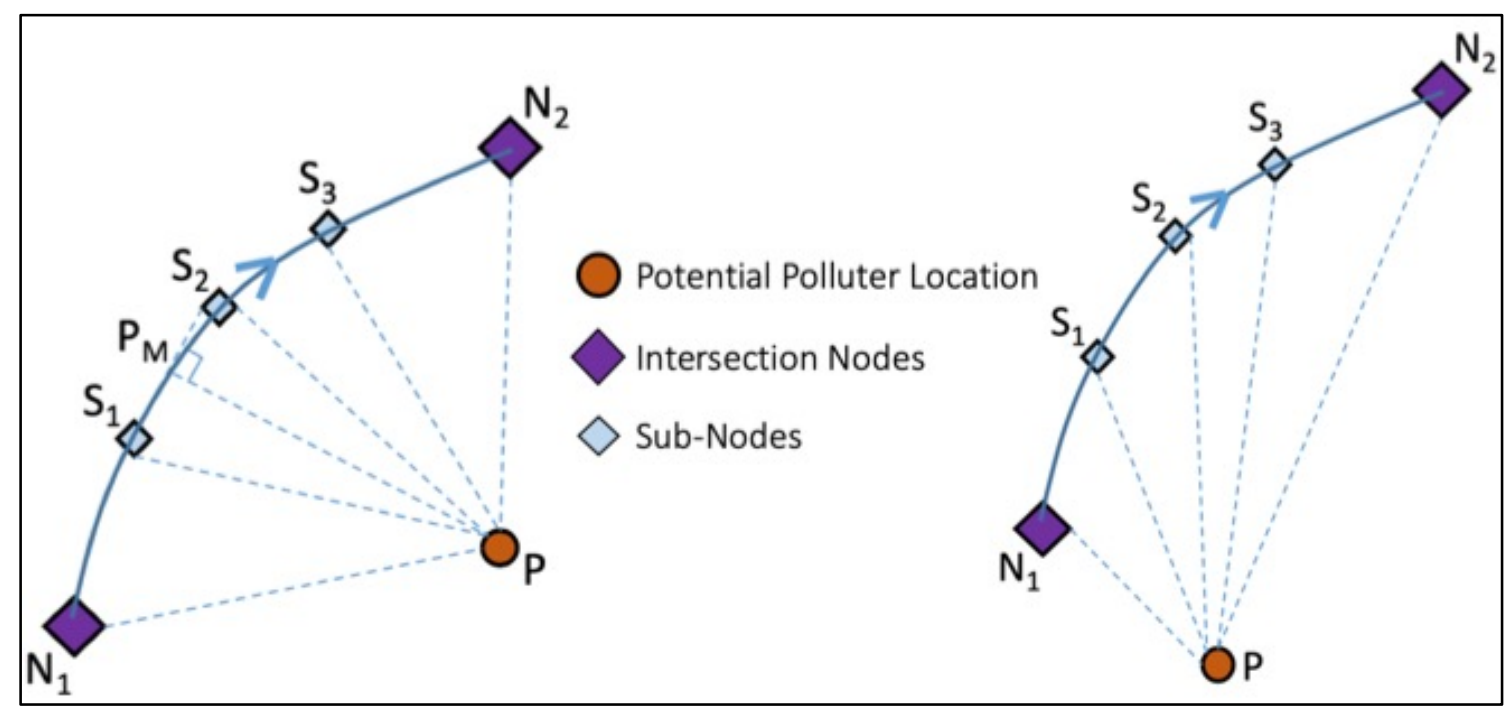

Figure S3. Illustration of (a) (left) C-PP location lying within the span of the nearest stream vs. (b) (right) C-PP location lying beyond the end node $\mathrm{N}_{1}$ of the stream.

While resolving these errors, as shown in the first case in Figure S3a, we drop a perpendicular from $\mathrm{P}$ onto the nearest sub edge formed by the nearest two sub-nodes, $S_{1}-S_{2}$. At the base of this perpendicular, we create a new intersection node, breaking the corresponding main edge and simultaneously creating two new edges. We refer to this new mapped node as $P_{M}$ and the corresponding two new edges are $N_{1}-P_{M}$ and $P_{M}-N_{2}$. We update the BRN and SPL adding these two new edges and stream paths while deleting the original stream $N_{1}-N_{2}$. In the second 
case (Figure S3b), we simply map P onto $N_{1}$, without any updates in BRN and SPL. The dynamic update allows distinct mapping of several nearby C-P locations onto a single stream without any discrepancy. We summarize this three-step mapping procedure in Algorithm 1.

\section{Motivation and Details of C-PP Transformation}

After the mapping procedure, we encountered two additional main challenges related to sparsity and long data extraction time.

One challenge comes from the general sparsity of monitoring sites, particularly a lack of upstream samples. Measurements along rivers are typically accomplished either with sensors (which tend to be expensive to maintain) or by hand (which is time-intensive and costly). Therefore, a very limited number of sites are monitored in most river networks. The lack of upstream samples in the same tributary as the polluter (Type I samples) often results in either no conclusion or a considerable decrease in the power of the tests used in the procedure. Another root cause of data sparsity arises due to higher likelihood of a mapped C-P location lying on a loworder stream. These low order streams are more prevalent and cover larger areas compared to major streams. To resolve this challenge, we consider a number of intersections in the vicinity of the potential polluter with tributaries that contain background samples unaffected by the event. We refer to these intersections as projected intersection nodes with respect to the polluter under consideration and the corresponding upstream samples as Type II background samples. These indirect samples serve as a background, improve the power of the tests, and become essential in detecting contamination in cases when there is no Type I upstream sample.

The other challenge comes from traversing the BRN from one $\mathrm{C}-\mathrm{P}$ location to another to collect data for inference. This happens due to big network size and inclusion of stream flow lines. The intermediate sub-nodes add to the memory requirements without holding much relevance. There are several instances when there is no direct edge between two non-adjacent mapped C-P locations in the updated BRN, although they are still connected by the river flow indirectly through several other nodes and sub-nodes. For the inference procedure, we need to consider these possible connections between C-P locations according to river flowlines. The intersections and sub-nodes that do not coincide with the mapped C-P locations are only relevant in dictating if the mapped locations are connected. However, due to large memory requirements, they make the network difficult to traverse, and extraction of data for inference in real time monitoring systems could be 
considerably slower. Additionally, we must include projected intersection nodes for traversal and extraction of Type II background samples which makes real time data extraction more time consuming. To resolve this challenge, we use a shortest path breadth-first search algorithm (Cormen et al., 2009) to transform the complex river network to a reduced network, a subset of updated BRN with nodes as mapped Contaminant and Polluter locations together with their Projected intersection intersections (Figure 2). We call this reduced network as C-PP network.

\section{Node Classification in the C-PP Network}

In Figure S4, we classify nodes in the transformed C-PP network taking different possibilities for C-mapped locations based on their flow distances with polluter location $\mathrm{P}$ and its projected nodes. Note we ignore sub-nodes since after the C-PP transformation, they become irrelevant. This classification shows how we could trace the network to extract sampling locations related to a given testing event location based on specified flow distance and time interval parameters.

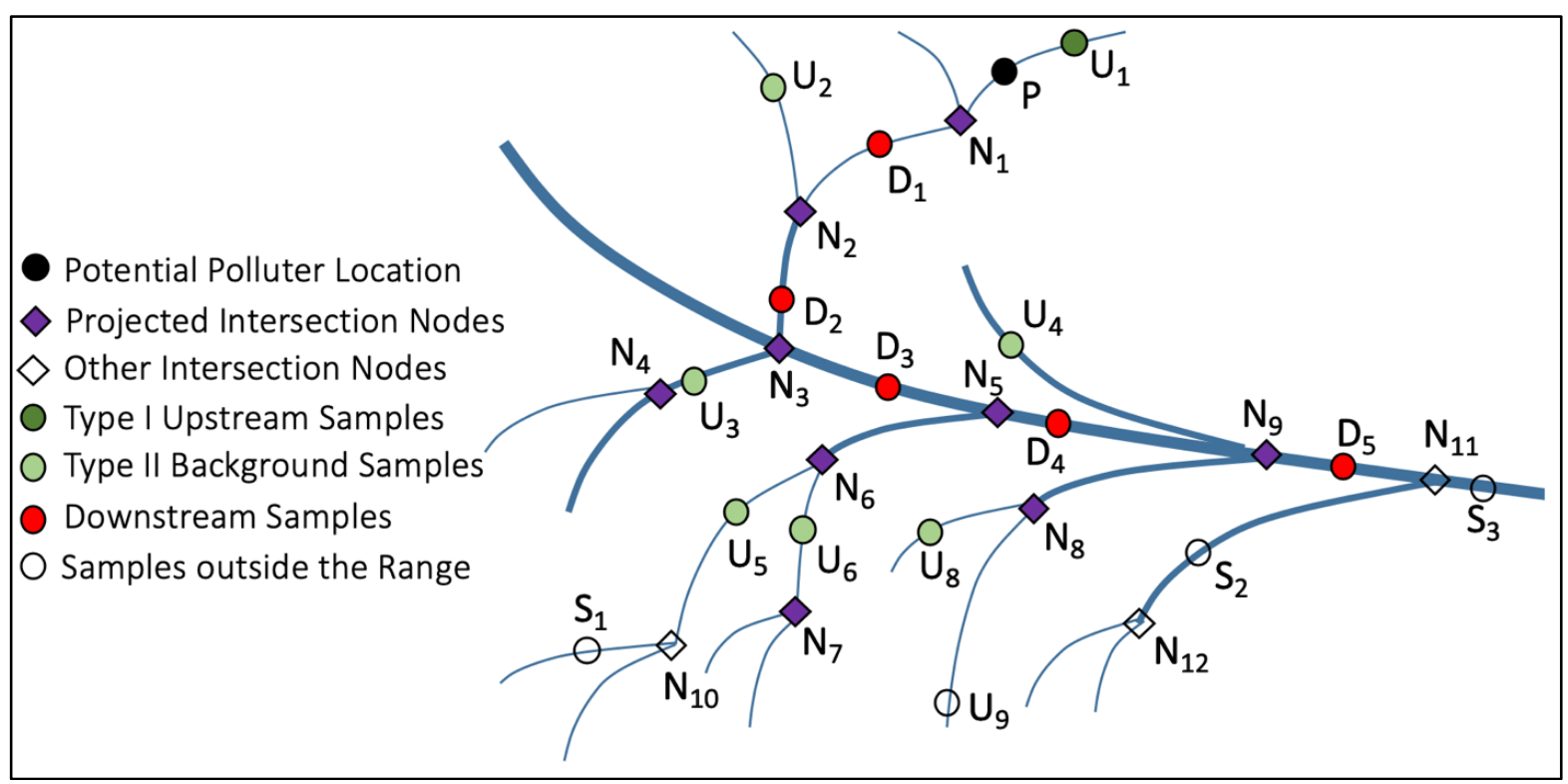

Figure S4. Illustration of node classification in a C-PP network for inference. Sampling locations are classified as Type I upstream and Type II background samples, downstream and outside the range based on their relative positions with respect to polluter location, its projected intersection nodes and flow distance parameters. $\mathrm{U}_{1}-\mathrm{U}_{9}$ represent upstream samples while $\mathrm{D}_{1}-\mathrm{D}_{5}$ are downstream samples.

In this example, $\mathrm{U}_{1}$ is the only Type I upstream sample. Starting from $\mathrm{P}$, we find the projected intersections $\left\{N_{i}\right\}_{i=1}^{9}$ that lie within distance $d_{P}$ along the river flow. $\left\{U_{i}\right\}_{i=2}^{8}$ refer to Type II background samples that serve as background from other sub-tributaries. $U_{9}$ is not a Type II 
background sample as it located $>5 \mathrm{~km}$ from the corresponding projected intersection. Each of these locations lie within the flow distance $d_{2 U}$ of one of the projected intersections. This automatically excludes sampling locations that are either (a) further away in branches of the projected nodes, e.g., $S_{1}$ lies beyond the distance $d_{2 U}$ relative to $N_{6}$, or (b) located in branches of intersections far away, e.g., $S_{2}$ lies in the branch of intersection $I_{2}$ that is located beyond $d_{P}$ relative to $\mathrm{P}$. The downstream samples $\left\{D_{i}\right\}_{i=1}^{5}$ lie within flow distance $d_{D}$. In the case study of PA spills, we choose $d_{P}=45 \mathrm{~km}, d_{1 U}=d_{2 U}=5 \mathrm{~km}$ and $d_{D}=50 \mathrm{~km}$, but in general these parameters could be case specific. The flexibility in modulating the threshold flow distances and hence spatial subset of samples used in the inference procedure, could change the test conclusion. In addition, each C-mapped node contains a temporal sequence of observations. This enables one to choose the time interval tailored for each testing event. 


\section{Text S2 Sequential Steps of GeoNet Algorithms}

\section{Sequential Steps for Algorithm 1 - Three-step Mapping Procedure}

INPUTS: BRN, SPL, list of unique C-PP locations PARAMETERS: $B=20$ (can be modulated but this works most of the time)

REPEAT FOR each C-PP location in sequence, Step 1:

(a) Calculate geodesics of the C-PP location with intersections in BRN.

(b) Identify nearest B intersections and extract corresponding streams from BRN and sub-list SPL.

Step 2:

(a) Calculate geodesics of the C-PP location with all sub-nodes in the sub-list.

(b) Identify the sub-nodes with smallest geodesic and extract the corresponding stream. Call it nearest stream (NS).

Step 3:

(a) Based on calculated geodesics with sub-nodes in NS, calculate the angle $\angle P N_{1} S_{1}$ for the nearest subnode.

(b) $\quad$ IF $\angle P N_{1} S_{1}<\pi / 2$

i. Drop perpendicular from $\mathrm{C}-\mathrm{PP}$ onto NS and map $\mathrm{C}-\mathrm{PP}$ on this new intersection node.

ii. Update BRN and SPL.

ELSE IF $\angle P N_{1} S_{1} \geq \pi / 2$

i. Map $\mathrm{C}-\mathrm{PP}$ on the nearest intersection node.

END FOR END IF

OUTPUTS: Updated BRN, Updated SPL, List of mapped C-PP locations.

\section{Sequential Steps for Algorithm 2 - Constructing C-PP Network}

INPUTS: Updated BRN, Updated SPL, List of mapped ContaminantPolluter (C-P) locations

PARAMETERS: Threshold flow distance of Polluter to Projected Intersections, $d_{P}=45 \mathrm{~km}$ (can be modulated flexibly)

REPEAT FOR each mapped C-P location in sequence,

obtain list of Projected nodes for each Polluter mapped location within flow distance $d_{P}$.

END FOR

REPEAT FOR each mapped $\mathrm{C}-\mathrm{P}$ mapped location and Projected Node in sequence,

Step 1: 
END FOR

Use breadth-first search to obtain shortest paths with every other mapped C-P location and Projected Node Step 2:

REPEAT FOR each shortest path sequence with length $>=1$,

(a) Extract all sub-node sequences making up the shortest path from updated SPL

(b) Initialize the cumulative flow distance counter for the shortest path

(c) REPEAT FOR each pair of adjacent nodes,

i. Calculate geodesics between all subnodes

ii. Add all geodesics

iii. Update the cumulative distance counter

END FOR END FOR

OUTPUT: C-PP Network edge list with shortest path flow distance for each edge

\section{Sequential Steps for Algorithm 3 - Three-step Inference Procedure}

INPUT: C-PP Network edge list with shortest path flow distance for each edge

PARAMETERS :

Threshold flow distances (can be modulated flexibly):

(a) Type I Upstream Samples from Polluter Node $d_{1 U}=5 \mathrm{~km}$

(b) Type II Background Samples from Projected Nodes $d_{2 U}=5 \mathrm{~km}$

(c) Downstream from Polluter Node $d_{D}=50 \mathrm{~km}$

Temporal intervals (can be modulated flexibly):

(a) Sampling Date Range for Upstream/Unaffected Samples = 01/01/1920 - 01/01/2018

(b) Sampling Date Range for Downstream Samples $=01 / 01 / 1920$ - 01/01/2018

REPEAT FOR each mapped C-PP location and Projected Node in parallel,

Step 1:

Conduct upstream temporal test sub-setting over

sampling locations within $d_{1 U}$ and $d_{2 U}$

Step 2:

Conduct downstream temporal test

Step 3:

Conduct upstream and downstream spatial-temporal test

END FOR

REPEAT FOR tests 2 and 3,

FDR CONTROL using Benjamini-Hochberg procedure END FOR

OUTPUT: List of significantly impacting events 


\section{Text S3 Details of Case Study for PA Spills}

\section{Spills Detected by Version 1 Tests}

Table S2. The list of PA spills ${ }^{1}$ detected by Version 1 tests.

\begin{tabular}{|c|c|c|c|c|c|c|c|c|c|c|c|}
\hline $\begin{array}{c}\text { Spill } \\
\text { Label }\end{array}$ & County & Date & Longitude & Latitude & $\begin{array}{l}\text { Volume } \\
\text { (gallons) }\end{array}$ & Spilled Material & $\begin{array}{c}\text { Upstream } \\
\text { Median (ppb) }\end{array}$ & $\begin{array}{c}\text { Downstream } \\
\text { Median (ppb) }\end{array}$ & $\begin{array}{l}\text { p values } \\
\text { (Test 1) }\end{array}$ & $\begin{array}{l}\text { p values } \\
\text { (Test 2) }\end{array}$ & $\begin{array}{l}\text { p values } \\
\text { (Test 3) }\end{array}$ \\
\hline Chloride & & & & & & & & & & & \\
\hline Tioga-1 & Tioga & $3 / 22 / 10$ & -76.965211 & 41.698031 & 1470 & \multirow{2}{*}{$\begin{array}{c}\text { Drilling Waste } \\
\text { Hydraulic Fracturing } \\
\text { Solution }\end{array}$} & 4900 & 8490 & 0.524 & 0.005 & 0.004 \\
\hline Greene- $1^{2}$ & Greene & $11 / 5 / 14$ & -80.248028 & 39.890522 & 16800 & & 23135 & 64200 & 0.337 & 0.006 & 0 \\
\hline Greene- $1^{2}$ & Greene & $11 / 5 / 14$ & -80.247889 & 39.890397 & 840 & $\begin{array}{c}\text { Hydraulic Fracturing } \\
\text { Solution }\end{array}$ & 23135 & 64200 & 0.337 & 0.006 & 0 \\
\hline Sodium & & & & & & & & & & & \\
\hline Tioga-2 & Tioga & $7 / 1 / 13$ & -76.949064 & 41.849486 & 2100 & Saltwater/Flowback & 5577.5 & 7099 & 0.052 & 0 & 0.005 \\
\hline
\end{tabular}
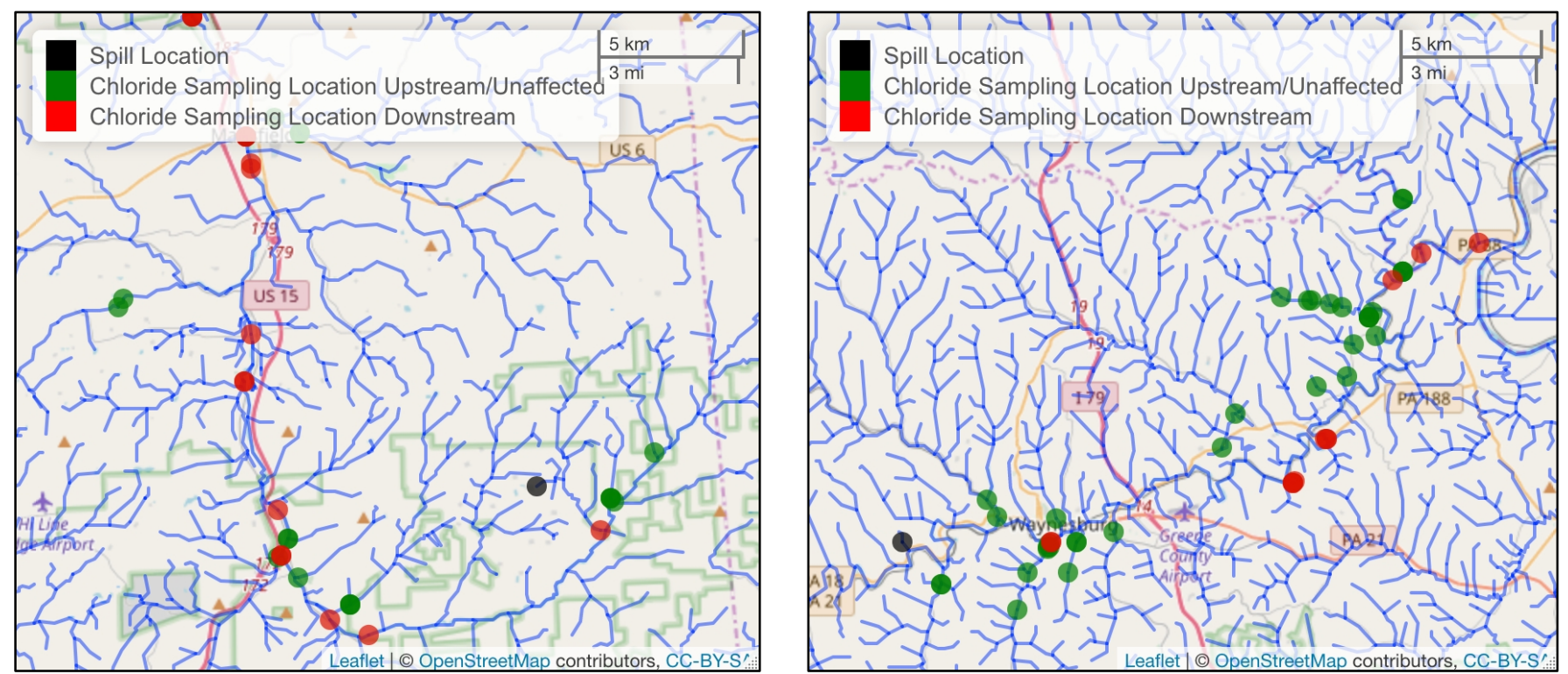

Figure S5. Chloride sampling sites for Tioga-1 spill (left) and Greene-1 spill (right). 


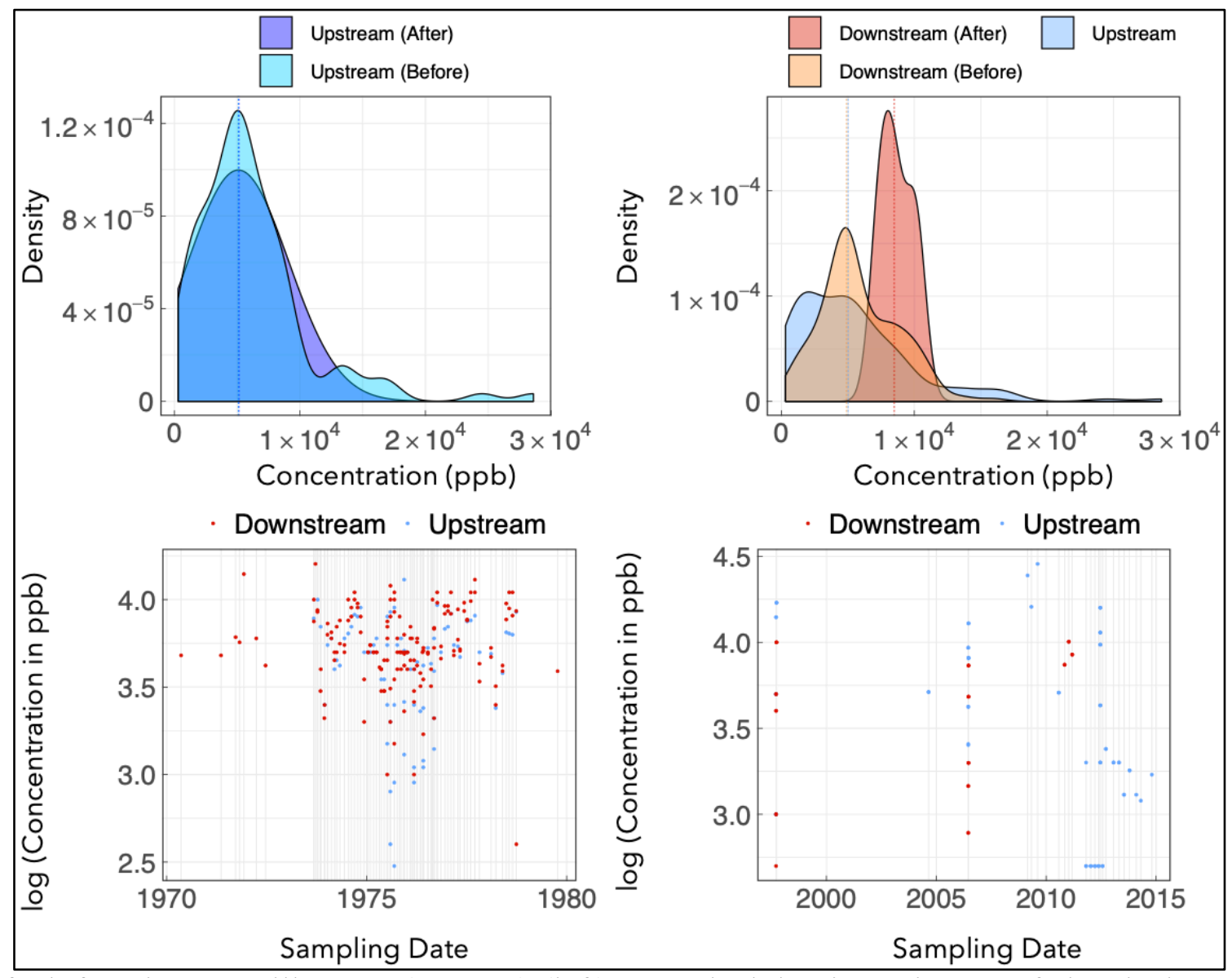

Figure S6. Analysis of $\mathrm{Cl}^{-}$for Tioga-1 spill event, (top row) (left) Smoothed density estimates of chemical concentrations comparing the background upstream samples before and after the event and (right) all upstream samples with downstream before and after the event; (bottom row) time series plots for upstream/unaffected (left) and downstream after (right). 


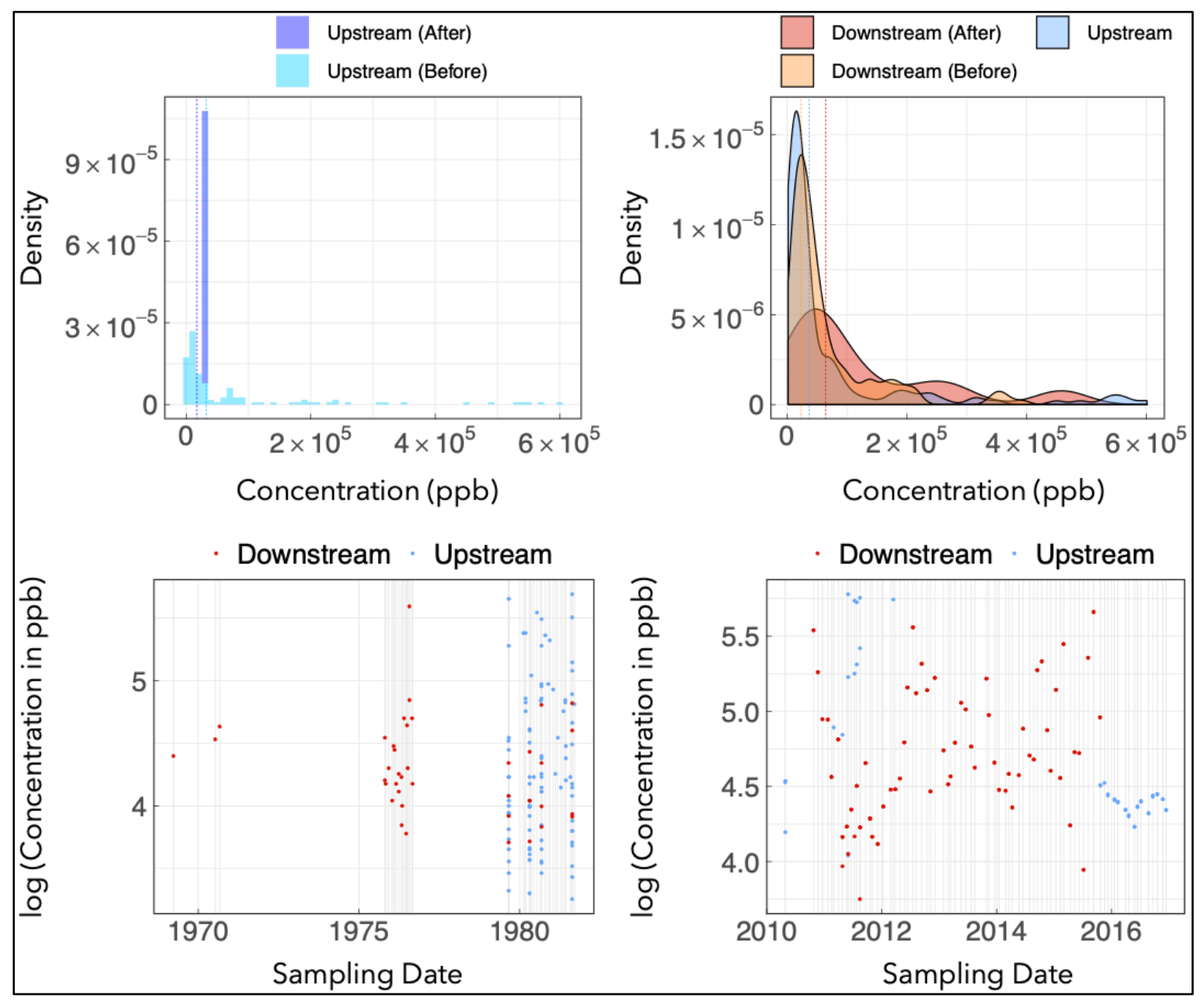

Figure S7. Analysis of Cl- for Greene-1 spill event, (top row) (left) Estimated densities of concentrations comparing the background upstream samples before and after the event and (right) all upstream samples with downstream before and after the event; (bottom row) time series plots for upstream/unaffected and downstream concentrations. 


\section{Additional Spills Detected by Version 2 Tests}

After controlling FDR in PA surface water data analysis, we provide the list of positive detections from the results of Version $2 \mathrm{Cl}$ tests excluding those spills already included in the list from Version 1 test (Table S3).

Table S3. The list of PA spills detected by Version 2 tests using chloride data (excluding spills shown in Table S2).

\begin{tabular}{|c|c|c|c|c|c|c|c|c|c|}
\hline County & Date & $\begin{array}{l}\text { Volume } \\
\text { (gallons) }\end{array}$ & Material & Operator & $\begin{array}{c}\text { Upstream } \\
\text { Median (ppb) }\end{array}$ & $\begin{array}{l}\text { Downstream } \\
\text { Median (ppb) }\end{array}$ & $\begin{array}{l}\text { p values } \\
\text { (Test 1) }\end{array}$ & $\begin{array}{l}\text { p values } \\
\text { (Test 2) }\end{array}$ & $\begin{array}{l}\text { p values } \\
\text { (Test 3) }\end{array}$ \\
\hline Tioga & $4 / 12 / 10$ & 400 & Diesel & Seneca Resources Corp & 5800 & 10270 & NA & 0.001 & 0.001 \\
\hline Tioga & $7 / 6 / 10$ & 1000 & Saltwater & SWEPI LP & 6980 & 9100 & 0.014 & 0.018 & 0.032 \\
\hline Tioga & $10 / 5 / 10$ & 630 & Drilling Waste & Tenaska Res LLC & 6000 & 8555 & NA & 0.016 & 0.003 \\
\hline Tioga & $11 / 9 / 11$ & 630 & Saltwater & SWEPI LP & 5900 & 8160 & NA & 0.004 & 0.003 \\
\hline Tioga & $6 / 1 / 12$ & 420 & Saltwater & Seneca Resources Corp & 5500 & 7910 & 0.022 & 0.001 & 0 \\
\hline Tioga & $8 / 6 / 12$ & 400 & Saltwater & SWEPI LP & 5900 & 10500 & NA & 0 & 0 \\
\hline Wyoming & $6 / 25 / 13$ & 420 & Drilling Waste & Cabot Oil \& Gas Corp & 11000 & 23600 & NA & 0 & 0.024 \\
\hline Tioga & $7 / 1 / 13$ & 2100 & Saltwater & SWEPI LP & 5900 & 11700 & NA & 0 & 0 \\
\hline Greene & $10 / 4 / 13$ & 945 & Unknown & CNX Gas Co LLC & 15700 & 46665 & NA & 0.019 & 0.001 \\
\hline Fayette & $1 / 13 / 14$ & 17640 & Saltwater & XTO Energy Inc & 13000 & 26700 & NA & 0.003 & 0.002 \\
\hline Susquehanna & $12 / 16 / 13$ & 2625 & Saltwater & Cabot Oil \& Gas Corp & 15200 & 26175 & NA & 0 & 0.001 \\
\hline Susquehanna & $11 / 25 / 14$ & 420 & Drilling Waste & Chief Oil \& Gas LLC & 10500 & 27600 & NA & 0 & 0.016 \\
\hline
\end{tabular}




\section{Additional Spills Detected by Version 3 Tests}

GeoNet allows us to detect even mild change in stream water chemistry as a result of polluting events. In Tables S4-S9, we provide a summary of positively detected spills by Version 3 tests with respect to different analytes excluding those already included in the lists for Version 1 and/or 2 tests.

Table S4. The list of PA spills detected by Version 3 tests (excluding spills shown in Table S2 and S3).

\begin{tabular}{|c|c|c|c|c|c|}
\hline County & Date & Volume & Material & Operator & Analytes \\
\hline Susquehanna & $2009-09-16$ & 1470 & Hydraulic Fracturing Solution & Cabot Oil \& Gas Corp & $\mathrm{Cl}$ \\
\hline Susquehanna & $2009-09-22$ & 420 & Hydraulic Fracturing Solution & Cabot Oil \& Gas Corp & $\mathrm{Cl}$ \\
\hline Cameron & 2009-09-30 & 2016 & Drilling Waste & Sampson Exploration LLC & $\mathrm{Br}$ \\
\hline Cameron & 2009-10-01 & 630 & Drilling Waste & Sampson Exploration LLC & $\mathrm{Br}$ \\
\hline Susquehanna & $2009-10-22$ & 420 & Drilling Waste & Chief Oil \& Gas LLC & $\mathrm{Cl}, \mathrm{Br}$ \\
\hline Bradford & $2009-11-23$ & 6000 & Saltwater & Talisman Energy Inc & $\mathrm{Br}, \mathrm{Ba}$ \\
\hline Tioga & 2010-01-06 & 4200 & Saltwater & SWEPI LP & $\mathrm{Br}, \mathrm{Ba}, \mathrm{Na}$ \\
\hline Tioga & $2010-03-22$ & 1470 & Drilling Waste & Talisman Energy Inc & $\mathrm{Br}, \mathrm{Ba}, \mathrm{Mg}$ \\
\hline Tioga & 2010-04-12 & 400 & Diesel & Seneca Resources Corp & $\mathrm{Br}$ \\
\hline Tioga & 2010-07-06 & 1000 & Saltwater & SWEPI LP & $\mathrm{Br}$ \\
\hline Bradford & $2010-09-20$ & 420 & Hydraulic Fracturing Solution & Talisman Energy Inc & $\mathrm{Br}, \mathrm{Ba}, \mathrm{Na}$ \\
\hline Susquehanna & 2011-01-10 & 6300 & Saltwater & Chief Oil \& Gas LLC & $\mathrm{Br}$ \\
\hline Susquehanna & 2011-03-04 & 420 & Drilling Waste & Southwestern Energy Production Co & $\mathrm{Br}$ \\
\hline Tioga & 2011-03-15 & 5300 & Saltwater & SWEPI LP & $\mathrm{Br}$ \\
\hline Susquehanna & 2011-03-30 & 840 & Drilling Waste & Carrizo (Marcellus) LLC & $\mathrm{Br}, \mathrm{Ba}$ \\
\hline Potter & 2011-05-11 & 504 & Saltwater & SWEPI LP & $\mathrm{Na}$ \\
\hline Bradford & 2011-06-24 & 800 & Saltwater & Talisman Energy Inc & $\mathrm{Cl}, \mathrm{Br}, \mathrm{Ba}$ \\
\hline Bradford & $2011-06-28$ & 16800 & Saltwater & Talisman Energy Inc & $\mathrm{Ba}$ \\
\hline Bradford & 2011-09-12 & 575 & Chemicals & SWEPI LP & $\mathrm{Ba}$ \\
\hline Bradford & 2012-01-10 & 16800 & Saltwater & Talisman Energy Inc & $\mathrm{Br}$ \\
\hline Tioga & 2012-06-01 & 420 & Saltwater & Seneca Resources Corp & $\mathrm{Br}$ \\
\hline Lycoming & $2012-07-03$ & 5460 & Saltwater & EXCO Resources PA LLC & $\mathrm{Br}$ \\
\hline Butler & 2012-11-14 & 546 & Saltwater & RE Gas Dev LLC & $\mathrm{Cl}, \mathrm{Br}, \mathrm{Ba}, \mathrm{Na}$ \\
\hline Butler & 2013-02-04 & 840 & Saltwater & RE Gas Dev LLC & $\mathrm{Cl}, \mathrm{Br}, \mathrm{Ba}, \mathrm{Na}$ \\
\hline Wyoming & 2013-04-30 & 11340 & Saltwater & Carrizo (Marcellus) LLC & $\mathrm{Cl}, \mathrm{Br}, \mathrm{Ba}, \mathrm{Mg}, \mathrm{Na}$ \\
\hline Susquehanna & 2013-06-05 & 7560 & Hydraulic Fracturing Solution & Cabot Oil \& Gas Corp & $\mathrm{Cl}$ \\
\hline
\end{tabular}




\begin{tabular}{cccccc}
\hline County & Date & Volume & Material & Operator & Analytes \\
\hline Susquehanna & $2013-06-03$ & 504 & Saltwater & Cabot Oil \& Gas Corp & $\mathrm{Cl}$ \\
Armstrong & $2013-07-09$ & 1470 & Saltwater & EXCO Resources PA LLC & $\mathrm{Cl}, \mathrm{Br}, \mathrm{Na}$ \\
Greene & $2013-07-30$ & 10000 & Saltwater & EQT Production Co & $\mathrm{Cl}$ \\
Susquehanna & $2013-07-26$ & 840 & Crude Oil & Chief Oil \& Gas LLC & $\mathrm{Cl}$ \\
Susquehanna & $2013-08-07$ & 948 & Diesel & CNX Gas Co LLC & $\mathrm{Ba}, \mathrm{Na}$ \\
Greene & $2013-10-04$ & 945 & Unknown & XTO Energy Inc & $\mathrm{Ba}$ \\
Fayette & $2014-01-13$ & 17640 & Saltwater & $\mathrm{Br}, \mathrm{Ba}, \mathrm{Na}$ \\
Greene & $2014-11-05$ & 16800 & Hydraulic Fracturing Solution Vantage Energy Appalachia II LLC & $\mathrm{Br}, \mathrm{Ba}, \mathrm{Na}$ \\
Greene & $2014-11-05$ & 840 & Hydraulic Fracturing Solution Vantage Energy Appalachia II LLC & VL Val \\
\hline
\end{tabular}


Table S5. The list of PA spills detected by Version 3 tests using chloride data (excluding spills shown in Table S2 and S3).

\begin{tabular}{|c|c|c|c|c|c|c|c|c|c|}
\hline County & Date & Volume & Material & Operator & $\begin{array}{c}\text { Upstream } \\
\text { Median (ppb) }\end{array}$ & $\begin{array}{c}\text { Downstream } \\
\text { Median (ppb) }\end{array}$ & $\begin{array}{l}\text { p values } \\
\text { (Test 1) }\end{array}$ & $\begin{array}{l}\text { p values } \\
\text { (Test 2) }\end{array}$ & $\begin{array}{l}\text { p values } \\
\text { (Test 3) }\end{array}$ \\
\hline Susquehanna & $2009-09-16$ & 1470 & $\begin{array}{c}\text { Hydraulic } \\
\text { Fracturing Solution }\end{array}$ & $\begin{array}{l}\text { Cabot Oil \& Gas } \\
\text { Corp }\end{array}$ & 10300 & 14500 & NA & 0.629 & 0.042 \\
\hline Susquehanna & $2009-09-22$ & 420 & $\begin{array}{c}\text { Hydraulic } \\
\text { Fracturing Solution }\end{array}$ & $\begin{array}{l}\text { Cabot Oil \& Gas } \\
\text { Corp }\end{array}$ & 10300 & 14500 & NA & 0.629 & 0.042 \\
\hline Susquehanna & $2009-10-22$ & 420 & Drilling Waste & Chief Oil \& Gas LLC & 10500 & 20200 & NA & 0.205 & 0.029 \\
\hline Bradford & 2011-06-24 & 800 & Saltwater & Talisman Energy Inc & 10000 & 14270 & 0.754 & 0.927 & 0.003 \\
\hline Butler & 2012-11-14 & 546 & Saltwater & RE Gas Dev LLC & 22630 & 88900 & 0.129 & 0.129 & 0 \\
\hline Butler & 2013-02-04 & 840 & Saltwater & RE Gas Dev LLC & 22420 & 88900 & 0.011 & 0.046 & 0 \\
\hline Wyoming & 2013-04-30 & 11340 & Saltwater & $\begin{array}{c}\text { Carrizo (Marcellus) } \\
\text { LLC }\end{array}$ & 10700 & 28080 & 0 & 0.099 & 0 \\
\hline Susquehanna & 2013-06-05 & 7560 & $\begin{array}{c}\text { Hydraulic } \\
\text { Fracturing Solution }\end{array}$ & $\begin{array}{c}\text { Cabot Oil \& Gas } \\
\text { Corp }\end{array}$ & 10000 & 13800 & NA & 0.103 & 0 \\
\hline Susquehanna & 2013-06-03 & 504 & Saltwater & $\begin{array}{c}\text { Cabot Oil \& Gas } \\
\text { Corp }\end{array}$ & 10300 & 14100 & 0 & 0.185 & 0.001 \\
\hline Greene & 2013-07-30 & 10000 & Saltwater & EQT Production Co & 25000 & 42185 & NA & 0.045 & 0.002 \\
\hline Susquehanna & $2013-07-26$ & 840 & Crude Oil & Chief Oil \& Gas LLC & 10300 & 13600 & 0 & 0.393 & 0.002 \\
\hline Susquehanna & 2013-08-07 & 948 & Diesel & Chief Oil \& Gas LLC & 10300 & 13600 & 0 & 0.393 & 0.002 \\
\hline
\end{tabular}


Table S6. The list of PA spills detected by Version 3 tests using bromide data (excluding spills shown in Table S2 and S3).

\begin{tabular}{|c|c|c|c|c|c|c|c|c|c|}
\hline County & Date & Volume & Material & Operator & $\begin{array}{c}\text { Upstream } \\
\text { Median (ppb) }\end{array}$ & $\begin{array}{l}\text { Downstream } \\
\text { Median (ppb) }\end{array}$ & $\begin{array}{l}\text { p values } \\
\text { (Test 1) }\end{array}$ & $\begin{array}{c}\text { p values } \\
\text { (Test 2) }\end{array}$ & $\begin{array}{l}\text { p values } \\
\text { (Test 3) }\end{array}$ \\
\hline Cameron & 2009-09-30 & 2016 & Drilling Waste & $\begin{array}{c}\text { Sampson Exploration } \\
\text { LLC }\end{array}$ & 25 & 100 & NA & NA & 0.004 \\
\hline Cameron & 2009-10-01 & 630 & Drilling Waste & $\begin{array}{c}\text { Sampson Exploration } \\
\text { LLC }\end{array}$ & 25 & 100 & NA & NA & 0.004 \\
\hline Susquehanna & $2009-10-22$ & 420 & Drilling Waste & Chief Oil \& Gas LLC & 10 & 100 & NA & 0.992 & 0.015 \\
\hline Bradford & $2009-11-23$ & 6000 & Saltwater & Talisman Energy Inc & 13.6 & 100 & NA & NA & 0.021 \\
\hline Tioga & 2010-01-06 & 4200 & Saltwater & SWEPI LP & 25 & 75 & NA & NA & 0 \\
\hline Tioga & 2010-03-22 & 1470 & Drilling Waste & Talisman Energy Inc & 16.4 & 75 & NA & NA & 0.01 \\
\hline Tioga & 2010-04-12 & 400 & Diesel & Seneca Resources Corp & 14.1 & 100 & NA & 0.906 & 0.017 \\
\hline Tioga & 2010-07-06 & 1000 & Saltwater & SWEPI LP & 25 & 100 & NA & 0.949 & 0 \\
\hline Bradford & 2010-09-20 & 420 & $\begin{array}{c}\text { Hydraulic Fracturing } \\
\text { Solution }\end{array}$ & Talisman Energy Inc & 18.8 & 100 & NA & NA & 0.004 \\
\hline Susquehanna & 2011-01-10 & 6300 & Saltwater & Chief Oil \& Gas LLC & 19 & 600 & 0.868 & NA & 0.029 \\
\hline Susquehanna & 2011-03-04 & 420 & Drilling Waste & $\begin{array}{l}\text { Southwestern Energy } \\
\text { Production Co }\end{array}$ & 50 & 600 & NA & NA & 0.017 \\
\hline Tioga & 2011-03-15 & 5300 & Saltwater & SWEPI LP & 14 & 600 & 0.718 & NA & 0.04 \\
\hline Susquehanna & 2011-03-30 & 840 & Drilling Waste & $\begin{array}{c}\text { Carrizo (Marcellus) } \\
\text { LLC }\end{array}$ & 23.3 & 50 & NA & 0.907 & 0 \\
\hline Bradford & 2011-06-24 & 800 & Saltwater & Talisman Energy Inc & 18.8 & 50 & NA & 0.963 & 0.025 \\
\hline Bradford & 2012-01-10 & 16800 & Saltwater & Talisman Energy Inc & 25.54 & 39.83 & 0.862 & 0.944 & 0.041 \\
\hline Tioga & 2012-06-01 & 420 & Saltwater & Seneca Resources Corp & 11 & 25 & NA & 1 & 0.003 \\
\hline Lycoming & 2012-07-03 & 5460 & Saltwater & $\begin{array}{c}\text { EXCO Resources PA } \\
\text { LLC }\end{array}$ & 11.5 & 25 & 0.825 & 1 & 0.022 \\
\hline Butler & 2012-11-14 & 546 & Saltwater & RE Gas Dev LLC & 50 & 100 & 0.969 & 0.518 & 0 \\
\hline Butler & 2013-02-04 & 840 & Saltwater & RE Gas Dev LLC & 50 & 100 & 0.78 & 0.665 & 0 \\
\hline Wyoming & 2013-04-30 & 11340 & Saltwater & $\begin{array}{c}\text { Carrizo (Marcellus) } \\
\text { LLC }\end{array}$ & 19.9 & 25.3 & 0.902 & 0.999 & 0.024 \\
\hline Greene & 2013-07-30 & 10000 & Saltwater & EQT Production Co & 41.92 & 136.28 & NA & 0.692 & 0.007 \\
\hline Greene & 2014-11-05 & 16800 & $\begin{array}{c}\text { Hydraulic Fracturing } \\
\text { Solution }\end{array}$ & $\begin{array}{c}\text { Vantage Energy } \\
\text { Appalachia II LLC }\end{array}$ & 41.92 & 200 & 0.978 & 0.77 & 0.024 \\
\hline Greene & 2014-11-05 & 840 & $\begin{array}{c}\text { Hydraulic Fracturing } \\
\text { Solution }\end{array}$ & $\begin{array}{l}\text { Vantage Energy } \\
\text { Appalachia II LLC }\end{array}$ & 41.92 & 200 & 0.978 & 0.77 & 0.024 \\
\hline
\end{tabular}


Table S7. The list of PA spills detected by Version 3 tests using barium data (excluding spills shown in Table S2 and S3).

\begin{tabular}{|c|c|c|c|c|c|c|c|c|c|}
\hline County & Date & Volume & Material & Operator & $\begin{array}{c}\text { Upstream } \\
\text { Median (ppb) }\end{array}$ & $\begin{array}{l}\text { Downstream } \\
\text { Median (ppb) }\end{array}$ & $\begin{array}{l}\text { p values } \\
\text { (Test 1) }\end{array}$ & $\begin{array}{l}\text { p values } \\
\text { (Test 2) }\end{array}$ & $\begin{array}{l}\text { p values } \\
\text { (Test 3) }\end{array}$ \\
\hline Bradford & $2009-11-23$ & 6000 & Saltwater & $\begin{array}{c}\text { Talisman } \\
\text { Energy Inc }\end{array}$ & 13 & 26 & NA & NA & 0.004 \\
\hline Tioga & 2010-01-06 & 4200 & Saltwater & SWEPI LP & 23 & 65.35 & NA & 0.572 & 0.002 \\
\hline Tioga & $2010-03-22$ & 1470 & $\begin{array}{l}\text { Drilling } \\
\text { Waste }\end{array}$ & $\begin{array}{l}\text { Talisman } \\
\text { Energy Inc }\end{array}$ & 13 & 64 & NA & NA & 0 \\
\hline Bradford & 2010-09-20 & 420 & $\begin{array}{l}\text { Hydraulic } \\
\text { Fracturing } \\
\text { Solution }\end{array}$ & $\begin{array}{l}\text { Talisman } \\
\text { Energy Inc }\end{array}$ & 30 & 70 & 0.406 & 0.382 & 0 \\
\hline $\begin{array}{l}\text { Susquehan } \\
\text { na }\end{array}$ & 2011-03-30 & 840 & $\begin{array}{l}\text { Drilling } \\
\text { Waste }\end{array}$ & $\begin{array}{c}\text { Carrizo } \\
\text { (Marcellus) LLC }\end{array}$ & 42 & 84 & NA & 0.448 & 0.001 \\
\hline Bradford & 2011-06-24 & 800 & Saltwater & $\begin{array}{l}\text { Talisman } \\
\text { Energy Inc }\end{array}$ & 30 & 53 & 0.9 & 0.057 & 0 \\
\hline Bradford & 2011-06-28 & 16800 & Saltwater & $\begin{array}{c}\text { Talisman } \\
\text { Energy Inc }\end{array}$ & 26.4 & 55 & 0.454 & 0.119 & 0.001 \\
\hline Bradford & 2011-09-12 & 575 & Chemicals & SWEPI LP & 25.95 & 34 & 0.742 & 0.333 & 0.005 \\
\hline Butler & $2012-11-14$ & 546 & Saltwater & $\begin{array}{l}\text { RE Gas Dev } \\
\text { LLC }\end{array}$ & 54 & 97.5 & 0.615 & 0.603 & 0.001 \\
\hline Butler & 2013-02-04 & 840 & Saltwater & $\begin{array}{l}\text { RE Gas Dev } \\
\text { LLC }\end{array}$ & 54.5 & 97.5 & 0.576 & 0.51 & 0.002 \\
\hline Wyoming & 2013-04-30 & 11340 & Saltwater & $\begin{array}{c}\text { Carrizo } \\
\text { (Marcellus) LLC }\end{array}$ & 30 & 86.5 & 0.281 & 0.257 & 0 \\
\hline Greene & 2013-10-04 & 945 & Unknown & $\begin{array}{c}\text { CNX Gas Co } \\
\text { LLC }\end{array}$ & 50 & 79 & NA & 0.816 & 0.001 \\
\hline Fayette & $2014-01-13$ & 17640 & $\begin{array}{l}\text { Saltwater } \\
\text { Hydraulic }\end{array}$ & $\begin{array}{l}\text { XTO Energy Inc } \\
\text { Vantage Energy }\end{array}$ & 42 & 100 & 0.688 & 0.312 & 0 \\
\hline Greene & 2014-11-05 & 16800 & $\begin{array}{l}\text { Fracturing } \\
\text { Solution }\end{array}$ & $\begin{array}{l}\text { Appalachia II } \\
\text { LLC }\end{array}$ & 62 & 98.5 & 0.166 & 0.333 & 0.001 \\
\hline Greene & 2014-11-05 & 840 & $\begin{array}{l}\text { Hydraulic } \\
\text { Fracturing } \\
\text { Solution }\end{array}$ & $\begin{array}{l}\text { Vantage Energy } \\
\text { Appalachia II } \\
\text { LLC }\end{array}$ & 62 & 98.5 & 0.166 & 0.333 & 0.001 \\
\hline
\end{tabular}


Table S8. The list of PA spills detected by Version 3 tests using magnesium data (excluding spills shown in Table S2 and S3).

\begin{tabular}{cccccccccc}
\hline County & Date & Volume & Material & Operator & $\begin{array}{c}\text { Upstream } \\
\text { Median (ppb) }\end{array}$ & $\begin{array}{c}\text { Downstream } \\
\text { Median (ppb) }\end{array}$ & $\begin{array}{c}\text { p values } \\
\text { (Test 1) }\end{array}$ & $\begin{array}{c}\text { p values } \\
\text { (Test 2) }\end{array}$ & $\begin{array}{c}\text { p values } \\
\text { (Test 3) }\end{array}$ \\
\hline Tioga & $\begin{array}{c}2010- \\
03-22\end{array}$ & \multirow{2}{*}{1470} & $\begin{array}{c}\text { Drilling } \\
\text { Waste }\end{array}$ & $\begin{array}{c}\text { Talisman Energy } \\
\text { Inc }\end{array}$ & 3565 & 6107 & 0.965 & 0.962 & 0.011 \\
Wyoming & $2013-$ & \multirow{2}{*}{11340} & Saltwater & $\begin{array}{c}\text { Carrizo } \\
\text { (Marcellus) LLC }\end{array}$ & 1920 & 5182 & 0.049 & 0.103 & 0 \\
\hline
\end{tabular}


Table S9. The list of PA spills detected by Version 3 tests using sodium data (excluding spills shown in Table S2 and S3).

\begin{tabular}{|c|c|c|c|c|c|c|c|c|c|}
\hline County & Date & Volume & Material & Operator & $\begin{array}{l}\text { Upstream } \\
\text { Median } \\
\text { (ppb) }\end{array}$ & $\begin{array}{c}\text { Downstream } \\
\text { Median } \\
\text { (ppb) }\end{array}$ & $\begin{array}{l}\text { p values } \\
\text { (Test 1) }\end{array}$ & $\begin{array}{l}\text { p values } \\
\text { (Test 2) }\end{array}$ & $\begin{array}{l}\text { p values } \\
\text { (Test 3) }\end{array}$ \\
\hline Tioga & $\begin{array}{l}2010-01- \\
06\end{array}$ & 4200 & Saltwater & SWEPI LP & 754 & 2120.5 & NA & 0.091 & 0 \\
\hline Bradford & $\begin{array}{l}2010-09- \\
20\end{array}$ & 420 & $\begin{array}{c}\text { Hydraulic Fracturing } \\
\text { Solution }\end{array}$ & Talisman Energy Inc & 7200 & 12000 & NA & 0.831 & 0.011 \\
\hline Potter & $\begin{array}{l}\text { 2011-05- } \\
11\end{array}$ & 504 & Saltwater & SWEPI LP & 1378.5 & 2400 & 0.275 & 0.543 & 0.003 \\
\hline Butler & $\begin{array}{l}\text { 2012-11- } \\
14\end{array}$ & 546 & Saltwater & RE Gas Dev LLC & 19200 & 41495 & 0.335 & 0.372 & 0.002 \\
\hline Butler & $\begin{array}{l}\text { 2013-02- } \\
04\end{array}$ & 840 & Saltwater & RE Gas Dev LLC & 19200 & 41490 & 0.429 & 0.141 & 0.001 \\
\hline Wyoming & $\begin{array}{l}\text { 2013-04- } \\
30\end{array}$ & 11340 & Saltwater & $\begin{array}{c}\text { Carrizo (Marcellus) } \\
\text { LLC }\end{array}$ & 7450 & 16800 & 0.066 & 0.566 & 0 \\
\hline Armstrong & $\begin{array}{l}\text { 2013-07- } \\
09\end{array}$ & 1470 & Saltwater & $\begin{array}{c}\text { EXCO Resources PA } \\
\text { LLC }\end{array}$ & 1480 & 8680 & NA & 0.919 & 0 \\
\hline Greene & $\begin{array}{l}\text { 2013-07- } \\
30\end{array}$ & 10000 & Saltwater & EQT Production Co & 7975.5 & 49200 & 1 & 0.546 & 0 \\
\hline Greene & $\begin{array}{l}\text { 2013-10- } \\
04\end{array}$ & 945 & Unknown & CNX Gas Co LLC & 5205 & 53700 & 1 & 0.221 & 0 \\
\hline Greene & $\begin{array}{l}\text { 2014-11- } \\
05\end{array}$ & 16800 & $\begin{array}{c}\text { Hydraulic Fracturing } \\
\text { Solution }\end{array}$ & $\begin{array}{c}\text { Vantage Energy } \\
\text { Appalachia II LLC }\end{array}$ & 7960 & 70550 & 1 & 0.22 & 0 \\
\hline Greene & $\begin{array}{l}\text { 2014-11- } \\
05\end{array}$ & 840 & $\begin{array}{c}\text { Hydraulic Fracturing } \\
\text { Solution }\end{array}$ & $\begin{array}{c}\text { Vantage Energy } \\
\text { Appalachia II LLC }\end{array}$ & 7960 & 70550 & 1 & 0.22 & 0 \\
\hline
\end{tabular}




\section{Spills Detected by Multiple Versions of One Analyte}

We assessed a more stringent test, namely simultaneous detection by multiple test Versions. Specifically, Versions $1+2+3$ for either $\mathrm{Na}$ or for $\mathrm{Cl}$ detected 23 and 11 incidents respectively (and 0 for $\mathrm{Mg}, \mathrm{Ba}, \mathrm{Br}$ ) (Table $\mathrm{S10}$ ). But domain knowledge highlights problems with this conclusion for some of the spills, leading to the inference that tests for Versions $1+2+3$ for just one analyte may often yield false positives. For example, Tioga-1 and Greene-1 spills (Table S2, Figures S5, S6, S7) were detected by the test (Versions 1+2+3) for Cl. But PA DEP (2018) noted that the spill of drilling waste at Tioga-1 (1470 gallons) was immediately ameliorated, making it unlikely to have reached the stream $\sim 200$ meters away. Furthermore, drilling waste (which can include drilling mud, drill cuttings, drilling fluid, cement, and/or tophole water) might or might not contain high $\mathrm{Cl}$, but if it did, it would be likely to contain $\mathrm{Na}$ and $\mathrm{Ba}$ as well, and Version 1 and 2 tests for $\mathrm{Na}$ and $\mathrm{Ba}$ did not detect the Tioga-1 spill. In addition, the spill occurred during winter when salts are used to de-ice roads (although weather data (http://www.wunderground.com) one week before and after the event indicate no major rain, ice, or snow storms). The Greene-1 spill may also be false positive. Two associated violation records of Greene-1 note that a large volume $(16,800$ and 840 gallons) was spilled, but the type of spilled fluid, hydraulic fracturing solution, is generally not saline. In addition, PA DEP (2018) stated that only 50 and 20 gallons of fluid left the well pad (approximated values self-reported by the operator). 


\section{Text S4 Application of GeoNet for Real-time Monitoring of Water Quality}

The examples explored so far were run using a priori knowledge of the location of a spill site: once the location was pinpointed, we tested upstream and downstream and before and after samples. We would eventually want to use GeoNet for real-time monitoring to find unreported contamination events. This would require ongoing comparisons of up- and downstream sites before and after any given time point for a subset of locations over a period of time, looking for hard-to-explain changes in water quality.

To explore such an approach, we ran GeoNet using $\mathrm{Cl}$ measurements for a set of 331 locations spaced every 3,000 meters across Tioga County in a grid (green, red, and gray circles in Figure S8). GeoNet was run for the date of March 22 $2^{\text {nd }}, 2010$ (i.e., the date of the Tioga-1 spill). We then assessed water chemistry before and after March 22 ${ }^{\text {nd }}, 2010$ in upstream and downstream streams nearby each site on the grid.

The date of March 22 $2^{\text {nd }}, 2010$ was chosen so that we can validate GeoNet results in this pilot test by checking if GeoNet successfully detected a spill in the vicinity of Tioga- 1 . The resolution of 3,000 meters was chosen to reduce computational time while ensuring a large enough number of sites that a few would fall within the vicinity of the Tioga-1 spill. Among the 331 monitoring sites, four of them are located within $3 \mathrm{~km}$ of the Tioga-1 spill (red star in Figure S8). GeoNet parameters (timelag, distance) were set as described in the main body of the manuscript.

For this pilot test for 331 sites, the three algorithms (i.e., three-step mapping, C-PP network construction, and statistical inference) of GeoNet took about 5, 90, and 3 computational hours, respectively. Two sites were positively detected as being near a spill location by all three test Versions for $\mathrm{Cl}$ (Table S11). The other two sites were detected positively by only Version 2 and 3 tests (the Version $1 \mathrm{Cl}$ test did not show positive detections at these two sites because of an insufficient number of upstream $\mathrm{Cl}$ samples). This suggests that GeoNet could indeed be applied to automatically detect unreported contamination events given the availability of dense network of monitoring locations. In this exercise, two other clusters of positive detection were also detected by GeoNet (Figure S8). Thus, two other grid sites (one in Pine Creek without much oil and gas production sites around; the other one in Lycoming Creek with both unconventional and conventional production sites in the vicinity area) could also have been locations of spills that were not reported. 


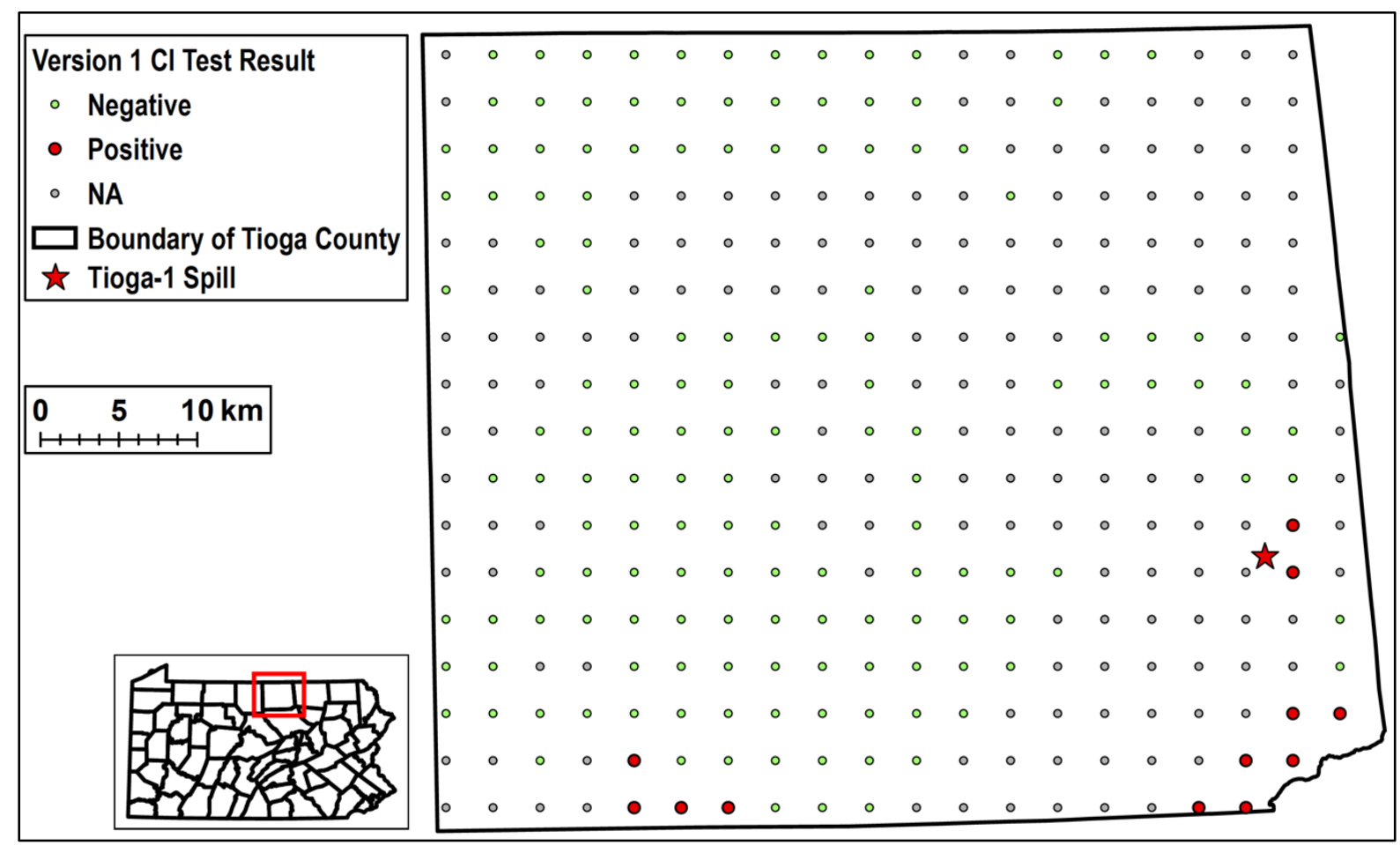

Figure S8. Results of Version $1 \mathrm{Cl}$ tests for 331 hypothetical monitoring sites in Tioga County. These monitoring sites are equally spaced at 3,000 meters. GeoNet was run for the date of March $22^{\text {nd }}, 2010$ (i.e., the date of the Tioga-1 spill at the location of the red star). For each grid location, we assessed the change in stream water chemistry before and after March 22 $2^{\text {nd }}, 2010$ in upstream and downstream samples. 


\section{References}

(1) Patterson, L. A.; Konschnik, K. E.; Wiseman, H.; Fargione, J.; Maloney, K. O.; Kiesecker, J.; Nicot, J. P.; Baruch-Mordo, S.; Entrekin, S.; Trainor, A.; Saiers, J. E. Unconventional Oil and Gas Spills: Risks, Mitigation Priorities, and State Reporting Requirements. Environ. Sci. Technol. 2017, 51 (5), 2563-2573. https://doi.org/10.1021/acs.est.6b05749.

(2) Maloney, K. O.; Baruch-Mordo, S.; Patterson, L. A.; Nicot, J. P.; Entrekin, S. A.; Fargione, J. E.; Kiesecker, J. M.; Konschnik, K. E.; Ryan, J. N.; Trainor, A. M.; Saiers, J. E.; Wiseman, H. J. Unconventional Oil and Gas Spills: Materials, Volumes, and Risks to Surface Waters in Four States of the U.S. Sci. Total Environ. 2017, 581-582, 369-377. https://doi.org/10.1016/j.scitotenv.2016.12.142.

(3) Cormen, T. H.; Leiserson, C. E.; Rivest, R. L.; Stein, C. Introduction to Algorithms; The MIT Press, 2009.

(4) Pennsylvania Department of Environmental Protection. PA DEP Oil\&Gas Compliance Report

http://www.depreportingservices.state.pa.us/ReportServer/Pages/ReportViewer.aspx?/Oil Gas/OG_Compliance (accessed Jan 1, 2018). 